\title{
in Technology
}

\section{Research paper}

Identification of the Appropriate Curing Method for Sri Lankan Turmeric (Curcuma longa L.) and Compare its Phytochemical Properties with an Indian Market Sample

\author{
Anuradha P. Munasinghe, ${ }^{a, b}$ Thushari Liyanage, ${ }^{b}$ and Chathuri \\ M. Senanayake $\mathrm{a}^{\mathrm{a},}$
}

a Department of Biosystems Technology, Faculty of Technology, University of Sri Jayewardenepura, Gangodawila, Nugegoda 10250, Sri Lanka

${ }^{b}$ Central Research Station, Department of Export Agriculture, Matale 21000, Sri Lanka Email correspondence: chathurisnnk@sjp.ac.lk (C. M. Senanayake)

Received: 30 March 2021; Revised: 27 April 2021; Accepted: 4 May 2021; Published: 31 May 2021

\begin{abstract}
Turmeric (Curcuma longa L.) is an underground rhizome that is an essential ingredient in day-to-day life. India is the major turmeric production and exportation country in the world. However, since December 2019, Sri Lanka has banned the importation of turmeric from other countries like India. Curing is a significant step during the processing of turmeric, which can be described as cooking fresh turmeric rhizomes before going to the drying step. Curing helps to avoid the raw odor, to reduce the drying time, to distribute the pigment product uniformly, and facilitate uniform drying. This study was conducted to identify the best protocol for turmeric processing and compare the quality of local turmeric samples prepared by using different processing steps such as, uncured and dried as slices, water boiled and dried as slices, steamed and dried as slices with imported turmeric from India. All the samples were separately analyzed for phytochemical properties (moisture content, volatile oil content, curcumin content, oleoresin content, etc.). Curcumin is an important attribute when considering the quality of turmeric. Curcumin content is varied with the curing step. The lowest curcumin content was shown by the uncured and sliced sample $(2.86$ $\pm 0.13 \%)$. Steamed and dried as slices sample showed the highest curcumin content $(4.51 \pm 0.02 \%)$. Curing and Slicing also decreased the drying time. However, water boiled and sliced sample (T-2) showed a high yield (wet to dry ratio 5.41:1), volatile oil content $4.40 \pm 0.00 \%$, and oleoresin content $14.81 \pm 2.36 \%$. According to the results, among the locally produced turmeric, steamed and dried as slices sample (T-3) showed good quality especially for curcumin content.
\end{abstract}

Keywords: Curcumin, curing, slices, steamed, water boiled 


\section{Introduction}

Turmeric (Curcuma longa L.) is an underground rhizome that belongs to the Zingiberaceae family. Turmeric is native to South Asia and about 110 species are widely distributed in the tropical and sub-tropical regions described by Li [1]. According to the study conducted by Plotto [2], India is popular for turmeric because of its high production and usage of turmeric. Turmeric has two types of metabolites such as primary and secondary metabolites. Primary metabolites include carbohydrates, protein, fat, and starch. Curcuminoid and essential oils are categorized under secondary metabolites according to Balasubramanian et al. [3] and Kutti et al [4]. When considering the yellow color of turmeric, it comes from the fat-soluble, polyphenolic pigment which is named curcuminoid. This compound contains curcumin, demethoxy curcumin, and bisdemethoxy curcumin as described by Hamar et al [5]. Li [1] mentioned that curcuminoid come under the group of diarylheptanoids. It is the main active compound in turmeric.

Turmeric is an essential ingredient in culinary preparation as described by Lokhande et al [6]. Turmeric pigment is important for the textile industry as a natural colorant mentioned by Jayashree et al [7]. As well as it is used in cosmetics and pharmaceuticals industries as described by Jayashree [8]. Lokhande et al. [6] explained numerous benefits of curcumin on preventing and treating some diseases. Niranjan et al. [9] described lots of pharmacological activities of turmeric that have been identified by different research. These pharmacological activities are due to the high content of curcumin. Important pharmacological activities include anti-parasitic, antispasmodic, anti-inflammatory, anticarcinogenic, and gastrointestinal effects, anti-parasitic and antiinflammatory activity. Turmeric oil is an effective treatment for respiratory diseases like asthma, sputum, and relieving cough explained by Cvetkovic et al [10].

Curing is the most important step in turmeric processing which involves the cooking of fresh rhizomes before drying. Cured rhizomes have better 
quality than uncured ones. It helps to avoid the raw odor, soften the tissues, and increase the removal of water at a very fast rate, and distribute the pigment product uniformly. As well as curing process facilitates starch gelatinization and uniform drying as discussed by Gagare [9] and Nair [10].

There are different curing methods. There is a simple method that follows the boiling of fresh rhizome in water until it starts frothing. This method follows the direct contact with boiling water in a barrel according to the explanation made by Lokhande et al [6]. This method is considered a low-cost method and requires no advanced knowledge. However, as reported by Chandrasekaran et al. [13] and Shinde et al. [14], this method has several drawbacks, such as overcooking of rhizomes due to the absence of an agitation method, need of higher labor requirement, loss of curcumin, inefficient and increased timeconsumption and oleoresin content by rubbing, brushing, etc. Jayashree et al. [7] explained that $5.85 \%$ of curcumin level, $13.33 \%$ of oleoresin content, and $3.60 \%$ of essential oil content resulted from the water boiling method.

Steam can be also used to cure fresh turmeric. Steaming results in several advantages over the water boiling method. Steaming facilitates uniform cooking and steam distribution throughout the mass, reduces energy consumption, and improves the quality of the products as mentioned by Shinde et al [14]. The need for higher labor, inefficient and timeconsuming, and loss of nutrients are of the drawbacks of this method as described by Biruk et al [15]. According to research studied by Jayashree et al. [7] curcumin, essential oil, oleoresin content varied with the boiling time. Higher retention of curcumin (5.91\%), oleoresin (13.33\%), and essential oil (3.6\%) were obtained for rhizomes cured by water boiling method for $40 \mathrm{~min}$ than $60 \mathrm{~min}$ and $90 \mathrm{~min}$.

Since 2019, Sri Lanka has banned the importation of turmeric from other countries like India to uplift local turmeric production by the local small- 
scale farmers. Therefore, identification of the best protocol for curing is an essential requirement.

The present study attempts to produce turmeric powder from local turmeric varieties by different curing methods and to determine and compare its phytochemical characteristics. The results will be also compared with that of turmeric powder imported from India to identify the best protocol for turmeric processing.

\section{Materials and Methods}

\section{Sample Collection}

This study was carried out in the Postharvest technology division, Central Research Station, Department of Export Agriculture, Matale. Local samples of Curcuma longa L. rhizomes were collected from local farmers in Riverston, Matale, Sri Lanka. Turmeric sample was imported from India to compare quality parameters with the local samples.

\section{Sample Preparation}

The collected rhizomes were separated into finger rhizomes and mother rhizomes. The separated finger rhizomes were taken to further analysis. The rhizomes were cleaned by washing using clean water until removed all the soil particles.

Thereafter, the local turmeric lot was divided into three groups and given different treatments.

$\mathrm{T}-1: 2 \mathrm{~kg}$ of fresh turmeric were cut into slices $(3 \mathrm{~mm})$ and then sent to a greenhouse-type solar dryer.

T-2: $2 \mathrm{~kg}$ of fresh turmeric fingers were immersed into stainless steel pot filled with boiling water for $30 \mathrm{~min}$, cut into slices $(3 \mathrm{~mm})$, and sent to a greenhouse-type solar dryer.

T-3: $2 \mathrm{~kg}$ of fresh turmeric were put into stainless steel steamer for 30 min, cut into slices $(3 \mathrm{~mm})$, and sent to a greenhouse-type solar dryer.

All samples were kept in a solar dryer until the samples reached a constant weight. All dried samples were ground well until passing through the $1 \mathrm{~mm}$ aperture. Then the samples were labeled and 
preserved under refrigerated conditions $\left(4^{\circ} \mathrm{C}\right)$.

Three types of imported Indian turmeric samples (T-4, T-5, and T-6) were analyzed to compare the phytochemical properties with the local turmeric samples. Fresh turmeric fingers packed in High-Density Polythene packaging under room temperature were imported from India. Turmeric powder was prepared by grinding the dried finger samples.

All samples were labeled and preserved under refrigerated conditions $\left(4{ }^{\circ} \mathrm{C}\right)$ until performing the analysis. Every analysis was triplicated.

\section{Determination of Moisture Content}

Dean and Stark Toluene Distillation method was used to determining the moisture content of ground turmeric according to the AOAC [16]. Toluene was used as the organic solvent to determine the water content. $10 \mathrm{~g}$ of turmeric powder was placed into the $250 \mathrm{ml}$ round bottom flask. Then about $50 \mathrm{ml}$ of toluene was added to the flask. The setup was run for 3 hours. Water collected in the graduated tube indicates the amount of water. The moisture content was calculated using following formula (1).

Moisture Content (\% by dry weight) $=\frac{V}{M} \times 100 \quad$ Equation 1 Where, $\mathrm{V}$ is the volume in $\mathrm{ml}$ of moisture collected, $\mathrm{M}$ is the weight of the sample.

\section{Determination of Volatile oil Content}

The Hydro-distillation method was conducted to determine the volatile oil content of ground turmeric powder according to the AOAC [14] with little modifications. $30 \mathrm{~g}$ of turmeric powder was measured and placed in a round-bottomed flask. Then about $300 \mathrm{ml}$ of distilled water was added to it. The flask with the content was heated for 4 hours and the apparatus was allowed to cool down. Finally, the volume of volatile oil was recorded. The volatile oil percentage was calculated using following formula (2). 
Volatile oil Content (\% by dry weight) $=\frac{V}{M} \times 100 \quad$ Equation 2 Where, $\mathrm{V}$ is the volume of volatile oil, $\mathrm{M}$ is the dry weight of the sample.

\section{Determination of Curcumin Content}

Determination of curcumin content was conducted according to the method of SLS 613: 1983 [17] with little modifications. $0.5 \mathrm{~g}$ of turmeric powder was placed in the round-bottomed flask. Then $30 \mathrm{ml}$ of $99.9 \%$ ethyl alcohol was added and the round bottom flask was connected with the refluxing condenser. The reflux was conducted for two and half hours and then the apparatus was allowed to cool down. Then the content was filtered through a filter paper into a $100 \mathrm{ml}$ volumetric flask. After that $1 \mathrm{ml}$ from that solution was placed into a $50 \mathrm{ml}$ volumetric flask. Finally, the absorbance was measured at $425 \mathrm{~nm}$ using a UV-VIS spectrophotometer (Cary 60 UV-VIS, Agilent Technologies, California, and USA). $99.9 \%$ ethyl alcohol was used as the blank sample. Curcumin content was calculated using following formula (3).

Curcumin content $(\%$ by dry weight $)=\frac{A \times 50 \times 100}{1607 \times m} \quad$ Equation 3

Where, $\mathrm{A}$ is the absorbance, $\mathrm{m}$ is the dry weight of the sample.

\section{Determination of Oleoresin Content}

Oleoresin was extracted from turmeric rhizomes using the method described by Singh et al [18]. Initially, $10 \mathrm{~g}$ of turmeric sample was placed inside a thimble which is loaded into the chamber of the Soxhlet extractor. A Chamber of Soxhlet extractor was placed into a flask containing the extraction solvent. Then absolute ethanol was poured into the main chamber until two siphons occurred. The Soxhlet chamber was then equipped with a condenser. The solvent was heated to reflux for over 16-18 hours. After many cycles, the compounds were concentrated in the solvent in the flask. The oleoresin content was calculated using following formula (4).

Oleoresin content $(\%$ by dry weight $)=\frac{(W 1-W)}{(W 2-M)} \times 100 \quad$ Equation 4 
Where, $\mathrm{W}$ is the weight of the flask, $\mathrm{W} 1$ is the weight of the flask + oleoresin, $\mathrm{W} 2$ is the weight of the sample and $\mathrm{M}$ is the moisture content of the sample.

\section{Determination of Total Ash and Acid Insoluble Ash Content}

Ash content was determined as mentioned in AOAC [14] with little modifications. $0.5 \mathrm{~g}$ of turmeric samples was ignited in the muffle furnace (Model CSF 11/13, Carbolite Gero, Parsons, United Kingdom) at $550^{\circ} \mathrm{C}$ for 3-4 hours and weight was recorded. As well as acid insoluble ash was determined by washing with diluted $\mathrm{HCl}$ according to the test method mentioned in AOAC [14]. The total ash content and acid insoluble ash content were calculated using following formulas (5) and (6) respectively.

Ash content ( $\%$ by dry weight)

$$
=\frac{\text { Weight of ash }}{\text { weight of the sample }} \times 100
$$

Equation 5

Acid insoluble ash content (\% by dry weight)

$$
=\frac{\text { Weight of acid insoluble ash }}{\text { Weight of the sample }} \times 100 \quad \text { Equation } 6
$$

\section{Determination of Total Phenol Content}

Total phenolic of Curcuma longa L. extracts was determined using the Folin-Ciocalteu (F-C) reagent, according to the method described by Huo et al and Gajula et al $[17,18]$. An aliquot of $0.125 \mathrm{ml}$ of diluted extract was added to $0.5 \mathrm{ml}$ of deionized water and $0.125 \mathrm{ml}$ of the (F-C) reagent. After shaking, the mixture was incubated for $3 \mathrm{~min}$ at room temperature. Then, $1.52 \mathrm{ml}$ of $7 \% \mathrm{Na}_{2} \mathrm{CO}_{3}$ solution was added. The volume obtained was adjusted to $3 \mathrm{ml}$ using distilled water, mixed vigorously, and held for $90 \mathrm{~min}$ at ambient temperature. The absorbance of the solution was then measured at $760 \mathrm{~nm}$ against distilled water as the blank using UVVIS spectrophotometer (Cary 60 UV-VIS, Agilent Technologies, California, and USA). The total phenolic content was expressed as mg of 
Gallic acid equivalents (GAE) per gram of dry weight through the calibration curve of Gallic acid.

\section{Determination of Total Flavonoids Content}

The total flavonoid content in ethanolic turmeric extracts was estimated according to the procedures described by Gajula et al [20]. $1 \mathrm{ml}$ of turmeric extract was taken into a test tube and $3 \mathrm{ml}$ of methanol was added to it. Then, $0.2 \mathrm{ml}$ of $10 \%$ aluminum chloride and $0.2 \mathrm{ml}$ of $1 \mathrm{M}$ potassium acetate were added into the same test tube respectively. After that, $5.6 \mathrm{ml}$ of distilled water was added into the same reaction mixture. Finally, the reaction mixture was incubated for $30 \mathrm{~min}$ at room temperature to complete the reaction. The absorbance of the solution was measured at $415 \mathrm{~nm}$ using a UV-VIS spectrophotometer (Cary 60 UV-VIS, Agilent Technologies, California, and USA).

The total flavonoid content was expressed as $\mathrm{mg}$ of quercetin equivalents per gram of dry weight through the calibration curve of quercetin.

\section{Determination of Crude Protein Content}

The crude protein content of turmeric was determined by using the micro Kjeldahl method stated in AOAC method [16]. $2 \mathrm{~g}$ of sample of turmeric powder was digested in a Kjeldahl kit for nearly 3 hours. After neutralization in the Kjeldahl instrument, released condensed fume was trapped in $4 \%$ Boric acid solution which was used then to titrate against $0.1 \mathrm{M} \mathrm{H}_{2} \mathrm{SO}_{4}$. The protein content of turmeric was calculated using nitrogen conversion factor 6.25 .

\section{Determination of Bulk Density}

Determination of bulk density was conducted according to the method of AOAC [16]. Turmeric powder was filled into a tared $500 \mathrm{ml}$ cylindrical container, little over its brim. Then by moving a thin glass rod, excess material was removed over the brim. The weight of the content was then measured. Three measurements were taken from each powder sample for higher accuracy. After that, the same container was tared and filled 
with water up to the brim and the volume of the water was measured by using a measuring cylinder. Three measurements were taken for the volume of water. The bulk density was calculated using following formula (7).

Bulk density $\left(\mathrm{g} / \mathrm{cm}^{3}\right)=\frac{\text { weight of the powder sample }}{\text { average volume of the water }} \quad$ Equation 7

\section{Determination of Color Content}

The color of the turmeric powder samples was determined using a chromameter (Model CR 10, Konica Minolita Sensing, Inc., Japan) based on the $L^{*}$ (lightness or brightness), $a^{*}$ (redness/greenness), $b^{*}$ (yellowness/blueness) values. Turmeric powder sample was taken into a clean petri dish with $3 \mathrm{~cm}$ depth. The measuring head of the chroma meter was carried near the surface of the sample and the values for $L^{*}$, $a^{*}, b^{*}$ were recorded. Three measurements were taken from each powder sample at 3 different positions.

\section{Determination of Morphology Content}

Determination of morphology of turmeric powder was conducted according to the method of Rafiqi et al [21]. A $0.5 \mathrm{~g}$ of sample was weighed into a cleaned beaker. Then, $5 \mathrm{ml} 50 \% \mathrm{HNO}_{3}$ and $10 \mathrm{ml}$ of distilled water were added to the sample. After that, the sample was kept in a water bath (Model MV2401, Electrothermal, London, England) until the sample started to boil. Then the samples were kept without any disturbance for overnight and the following day it was centrifuged at $1800 \mathrm{rpm}$ for 20 minutes. Then a drop of the centrifuged sample was observed under a biological microscope (Model SOLARIS-T-LED, BEL Engineering, and Milano, Italy) with $\times 400$ magnification and the examined microscopic views were captured by using "BEL CAPTURE" software.

\section{Statistical Analysis}

The treatments were analyzed separately for chemical and physical characteristics. Values were expressed as the mean \pm standard deviations for triplicates. The statistical analysis of data was performed using 
ANOVA to determine the significance of each parameter $(p \leq 0.05)$ among treatments and followed by a comparison among the treatments using the Tukey pairwise comparison test by the statistical software Minitab Version 19.

\section{Results and Discussion}

\section{Determination of Drying Period and Wet: Dry Ratio}

Treated turmeric samples were separately dried in a solar dryer in the Department of Export Agriculture. T-2 sample completed the drying within two days. Sliced, water boiling samples took 2 days and sliced, steamed samples took 3 days for complete drying. But uncured, sliced sample have been taken twelve days to dry (Table 1). Bhat et al. [22] declared that steaming softens the tissues and reduces the drying time of turmeric.

Table 1. Drying period and wet to dry ratio of turmeric samples

\begin{tabular}{lcc} 
Sample & No. of days for drying & Wet: dry ratio (kg) \\
\hline $\begin{array}{l}\text { Uncured, dried as slices } \\
(\mathrm{T}-1)\end{array}$ & 12 & $6.67: 1$ \\
$\begin{array}{l}\text { Water boiled, dried as } \\
\text { slices (T-2) }\end{array}$ & 2 & $5.41: 1$ \\
$\begin{array}{l}\text { Steamed boiled, dried as } \\
\text { slices (T-3) }\end{array}$ & 3 & $6.67: 1$
\end{tabular}

Drying is a method of food preservation. That is an essential step in the food industry. Drying involves removing moisture from food because moisture is necessary for the bacterial growth that causes food spoilage and deterioration as described by Hirun et al [23].

Drying time is reduced when sliced the rhizomes. Jayashree [8] indicated that the drying time was reduced significantly to five days when the turmeric is sliced. As well as in Jayashree and John Zachariah described that water boiling ( $40 \mathrm{~min}$ ) and dried as finger samples were taken 11 days for drying. 


\section{Determination of Moisture Content}

The highest moisture content was recorded for the T-4 (10.99 $\pm 0.00 \%)$ and T-5 (10.99 $\pm 0.00 \%)$ turmeric samples which are imported from India. The lowest mean moisture content was recorded for T-1 (9.97 \pm 0.01) which was the uncured, sliced sample (Table 2).

According to the Department of Export Agriculture in Sri Lanka, the moisture content of dry turmeric should be 6-13\%. As well as according to the standards specified in SLS, the maximum moisture content of turmeric powder should be $10.0 \%$. Not only that, the maximum amount of moisture content given by the standards in Indian Standards Institute and ASTA recommendation of ground turmeric is $10 \%$ and $9 \%$ respectively.

Ama et al. [24] indicated that the quality (biochemical constitute) of the turmeric is influenced at various levels of moisture content. When the turmeric is dried, water-soluble compounds can be lost. Therefore, recommended moisture content is essential to maintain.

\section{Determination of Volatile oil Content}

The highest volatile oil content was shown in the T-2 sample (water boiled, sliced sample). It was about $4.40 \pm 0.00 \%$ and the lowest oil content was shown in the T-3 sample with $3.70 \pm 0.00 \%$ which was the steamed and sliced sample (Table 2). The volatile oil contains highly volatile compounds with low boiling points. These might be lost during different processing steps like slicing, heating, drying as described by Dosoky et al [25].

According to the standard quality specification stated by the Department of Export Agriculture, the volatile oil content of turmeric is 3-5\%. According to the results, all the samples were in the expected volatile oil range.

\section{Determination of Curcumin Content}

The highest curcumin content has been reported in T-3 sample $4.51 \pm$ $0.01 \%$ which was treated as steamed, sliced sample. T-1 sample showed 
the less curcumin content $2.86 \pm 0.13 \%$ that was uncured, sliced sample (Table 2). The steamed and sliced sample had high curcumin content than water boiled, sliced sample. The steamed method has no direct contact with turmeric but the water boiling method has direct contact with turmeric. Therefore, curcumin can be leached into the water as described by Chandrasekaran et al [13].

According to the Sri Lankan Standard Institute (SLSI) under the specification for turmeric powder SLS 613:2007, the minimum requirement for curcumin is 3\% by mass. All the cured samples have fulfilled this requirement. But uncured sample had a lesser curcumin content than other samples. Nair [12] explained by cooking is responsible for the uniform color distribution of the final product. As well as Indian samples T-4, T-5, and T-6 also showed less curcumin content as $3.16 \pm 0.00 \%, 3.93 \pm 0.00 \%$, and $3.34 \pm 0.00 \%$ respectively however, they have met the SLSI requirement.

Curcumin is a natural orange-yellow color. It can be categorized under organic materials according to Kane et al [26]. Curcumin is sensitive to light. Therefore, during the analysis, the sample was covered well by Aluminum foil.

\section{Determination of Oleoresin Content}

The highest oleoresin content was shown T-2 sample which was $14.81 \pm$ $2.36 \%$. The lowest oleoresin content was recorded for the T-1 sample which was $10.29 \pm 0.50 \%$ (Table 2).

Oleoresin yield depends on the extraction temperature, solid-to-solvent ratio, and particle size. Several research studies reported that the oleoresin yield $(>8.03 \%$ dry basis) is higher with the higher solid-tosolvent $(15-25 \%)$ and higher temperature $\left(>45{ }^{\circ} \mathrm{C}\right)$. However, high oleoresin content can be obtained with low temperature and low solidto-solvent ratio with very low particle size from 0.38 to $0.15 \mathrm{~mm}$ according to Haldar et al [27]. 
Table 2. Moisture content, volatile oil content, oleoresin content of turmeric samples

\begin{tabular}{|c|c|c|c|c|}
\hline Treatments & $\begin{array}{c}\text { Moisture } \\
\text { content (\%) }\end{array}$ & $\begin{array}{c}\text { Volatile } \\
\text { oil } \\
\text { content } \\
(\%)\end{array}$ & $\begin{array}{l}\text { Curcumin } \\
\text { content }(\%)\end{array}$ & $\begin{array}{l}\text { Oleoresin } \\
\text { content }(\%)\end{array}$ \\
\hline $\begin{array}{l}\text { Uncured, dried as slices } \\
(\mathrm{T}-1)\end{array}$ & $9.97 \pm 0.01^{\mathrm{d}}$ & $\begin{array}{l}4.07 \pm \\
0.00^{\mathrm{d}}\end{array}$ & $2.86 \pm 0.13^{f}$ & $10.29 \pm 0.50^{\mathrm{b}}$ \\
\hline $\begin{array}{l}\text { Water boiled, dried as } \\
\text { slices (T-2) }\end{array}$ & $9.00 \pm 0.00^{\mathrm{e}}$ & $\begin{array}{l}4.40 \pm \\
0.00^{\mathrm{a}}\end{array}$ & $4.08 \pm 0.00^{\mathrm{b}}$ & $14.81 \pm 2.4^{a}$ \\
\hline $\begin{array}{l}\text { Steamed boiled, dried as } \\
\text { slices (T-3) }\end{array}$ & $\begin{array}{c}10.00 \pm \\
0.00^{c}\end{array}$ & $\begin{array}{c}3.70 \pm \\
0.00 \mathrm{e}\end{array}$ & $4.51 \pm 0.02^{\mathrm{a}}$ & $14.54 \pm 0.52^{\mathrm{a}}$ \\
\hline Indian sample (T-4) & $\begin{array}{c}10.99 \pm \\
0.00^{\mathrm{a}}\end{array}$ & $\begin{array}{c}3.37 \pm \\
0.00^{\mathrm{f}}\end{array}$ & $3.16 \pm 0.00 \mathrm{e}$ & $13.59 \pm 0.89 a, b$ \\
\hline Indian sample (T-5) & $\begin{array}{c}10.99 \pm \\
0.00^{\mathrm{a}}\end{array}$ & $\begin{array}{l}4.12 \pm \\
0.00^{\mathrm{b}}\end{array}$ & $3.93 \pm 0.00^{c}$ & $14.11 \pm 0.68^{a}$ \\
\hline Indian sample (T-6) & $\begin{array}{c}10.97 \pm \\
0.00^{\mathrm{b}}\end{array}$ & $\begin{array}{l}4.12 \pm \\
0.00^{c}\end{array}$ & $3.34 \pm 0.00^{\mathrm{d}}$ & $14.12 \pm 2.23^{a}$ \\
\hline
\end{tabular}

Values represent the mean of triplicate \pm standard deviation; in each column, means with the same letter (a, b, c, d, e, and f) are significantly different (Tukey's method, $p \leq 0.05$ ).

\section{Determination of Total Ash Content}

Determining the total ash content is an important index for nutritional evaluation. Ash refers to the inorganic residue remaining after the complete ignition of organic matter in the foodstuff. The ash content is a measure of the total amount of minerals present within a food.

The highest total ash content was shown for the T-3 sample $(11.29 \pm 0.67$ $\%$ ), which was the steamed and sliced sample. T-6 sample showed the lowest total ash content of $7.11 \pm 0.70 \%$ which was an Indian sample (Table 3). According to the SLS specification of 613:2007, the maximum 
total ash content is $9 \%$. But the total ash content is more than $9 \%$ in some local turmeric powder.

According to the Indian Standards Institute and the Standards of food and Agriculture Organization (FAO) in the United State, the maximum level of total ash content is $9 \%$. Almost all the Indian samples have been met this requirement.

Ash content in turmeric powder could be influenced by several factors such as cultural practices, environmental and geographical factors as discussed by Nisar et al [28].

\section{Determination of Acid Insoluble Ash Content}

The maximum acid insoluble ash content is shown by the T-3 sample $0.73 \pm 0.07 \%$ while minimum acid insoluble ash content is recorded for the T-1 sample with a value of $0.12 \pm 0.02 \%$ (Table 3). According to the SLS specification 613: 1983, the maximum allowable acid insoluble ash content is $1 \%$. As well as, according to the SLS specification of 618:2007 and the Food Act, No 26 of 1980 in Sri Lanka indicates that the acid insoluble ash content should not exceed $1.5 \%$. Almost all the sample showed values in the acceptable level range.

Acid insoluble ash contents are important parameters to identify the quality as well as the authenticity of the foods. Total ash content is insufficient to assess the quality because of environmental contaminations like sand and soil. Thus, the acid-insoluble ash content is an important index to illustrate the purity of medicinal plants explained by Rao et al [29]. As well as harvesting and processing techniques affect the acid insoluble ash content of final turmeric powder.

Since all turmeric samples are processed by following the recommendations of the Department of Export Agriculture, less amount 
of acid insoluble ash content resulted. It reflects a clear indication of the purity level of turmeric powder.

\section{Determination of Total Phenol Content}

Phenols are very important compounds because of their scavenging ability due to their hydroxyls group as described by Shahat et al [30]. The color and the medicinal activities (anti-inflammatory, antioxidant and anticancer activities, etc.) of turmeric are due to phenolic compounds of curcumin as described by Pundarikakshudu [31] and Sign et al [18]. The total phenolic content is changed with the extraction temperature, solvent-to-solid ratio, and particle size. Some researchers have described, total phenolic content increased when increase the extraction temperature up to $53.75{ }^{\circ} \mathrm{C}$. However, total phenolic content is decreased when the temperature goes up further according to research performed by Haldar et al [32]. Hirun et al [23] indicated that the amount of total phenolic content in turmeric varies with growth area, harvesting season, and turmeric varieties.

The highest phenolic content of turmeric powder has been recorded in Indian samples of T-5, T-4, and T-6 which were $263.97 \pm 0.50 \mathrm{GAE} \mathrm{mg} / \mathrm{g}$, $259.15 \pm 0.08 \mathrm{GAE} \mathrm{mg/g}$, and $251.35 \pm 1.11 \mathrm{GAE} \mathrm{mg/g} \mathrm{respectively.}$ According to the local turmeric samples, the T-3 sample showed a high phenolic content that was 225.66 $\pm 0.19 \mathrm{GAE} \mathrm{mg/g}$ than the other local samples. The lowest phenolic content showed in T-2 was $171.23 \pm 0.36$ GAE mg/g (Table 3).

\section{Determination of Total Flavonoid Content}

Turmeric also contains flavonoids. Eighteen flavonoids have been isolated and identified as one of them are flavanonol, five of flavones, and eleven of flavanols. explained by Meng et al [33]. 
The maximum amount of total flavonoid content in turmeric showed for the T-1 sample which belongs to the uncured step. Result was $261.40 \pm$ $0.43 \mathrm{mg}$ quercetin equivalent/g. the minimum amount of flavonoid content shown in water boiled sample of T-2 (79.70 $\pm 0.32 \mathrm{mg}$ quercetin equivalent/g) (Table 3).

\section{Determination of Crude Protein Content}

The highest crude protein content has been shown in water-boiled samples of T-2 which was $11.48 \pm 0.90 \%$. All the Indian samples of T-4, T-5, and T- 6 have shown less protein content than the local sample which were $6.07 \pm 1.42 \%, 6.24 \pm 0.48 \%$, and $5.40 \pm 0.91 \%$ respectively (Table 3).

According to the recommendation of the Department of Export Agriculture, recommended level for the protein content of the turmeric is $6-8 \%$.

Some research articles showed that the protein content of Curcuma longa is about $4.8 \mathrm{~g} / 100 \mathrm{~g}$. Some amino acids in Curcuma longa were identified by Sharma et al. [34] include Leucine, Valine, Lysine, Threonine, Phenylalanine, Isoleucine, Methionine, Histidine, Alanine, Arginine, Aspartic acid, Cystine, Glutamic acid, Glycine, Proline, Serine, and Tyrosine.

\section{Determination of Bulk Density}

T-1 sample showed the lowest bulk density about $0.32 \mathrm{~g} / \mathrm{cm}^{3}$. The uncured sample showed a significant difference from the cured sample (Table 4).

The density of food powder depends on the combined effects of moisture content, particle size, particle size distribution, particle shape, and inter-particle cohesion force described by Saifullah et al [35]. 
Table 3. Protein content, total ash content, acid insoluble ash content, total phenol content, total flavonoid content of turmeric powder

\begin{tabular}{|c|c|c|c|c|c|}
\hline Treatments & $\begin{array}{c}\text { Protein } \\
\text { content } \\
(\%)\end{array}$ & $\begin{array}{c}\text { Ash } \\
\text { content (\%) }\end{array}$ & $\begin{array}{c}\text { Acid } \\
\text { insoluble } \\
\text { Ash } \\
\text { content } \\
(\%)\end{array}$ & $\begin{array}{c}\text { Phenol } \\
\text { content } \\
\text { (GAEmg/g) }\end{array}$ & $\begin{array}{l}\text { Flavonoid } \\
\text { content } \\
\text { (mg } \\
\text { quecertin } \\
\text { equivalent/ } \\
\text { g) }\end{array}$ \\
\hline $\begin{array}{l}\text { Uncured, } \\
\text { dried as } \\
\text { slices (T-1) }\end{array}$ & $\begin{array}{l}6.05 \pm \\
0.33^{c}\end{array}$ & $\begin{array}{c}10.16 \pm \\
0.06^{\mathrm{a}}\end{array}$ & $\begin{array}{c}0.12 \pm \\
0.02^{\mathrm{d}}\end{array}$ & $\begin{array}{c}211.52 \pm \\
0.51^{\mathrm{e}}\end{array}$ & $\begin{array}{c}261.40 \pm \\
0.43^{\mathrm{a}}\end{array}$ \\
\hline $\begin{array}{l}\text { Water } \\
\text { boiled, dried } \\
\text { as slices (T-2) }\end{array}$ & $\begin{array}{c}11.48 \pm \\
0.90^{\mathrm{a}}\end{array}$ & $\begin{array}{l}7.72 \pm \\
0.25^{\mathrm{b}, \mathrm{c}}\end{array}$ & $\begin{array}{l}0.27 \pm \\
0.04^{\mathrm{b}, \mathrm{c}}\end{array}$ & $\begin{array}{c}171.23 \pm \\
0.36^{\mathrm{f}}\end{array}$ & $\begin{array}{c}79.70 \pm \\
0.32^{\mathrm{f}}\end{array}$ \\
\hline $\begin{array}{c}\text { Steamed, } \\
\text { dried as } \\
\text { slices (T-3) }\end{array}$ & $\begin{array}{c}9.04 \pm \\
0.30^{\mathrm{b}}\end{array}$ & $\begin{array}{c}11.29 \pm \\
0.67^{a}\end{array}$ & $\begin{array}{c}0.73 \pm \\
0.08^{\mathrm{a}}\end{array}$ & $\begin{array}{c}225.66 \pm \\
0.19^{d}\end{array}$ & $\begin{array}{c}156.52 \pm \\
0.07^{\mathrm{d}}\end{array}$ \\
\hline $\begin{array}{c}\text { Indian } \\
\text { sample }(\mathrm{T}-4)\end{array}$ & $\begin{array}{c}6.07 \pm \\
1.42^{c}\end{array}$ & $\begin{array}{l}7.89 \pm \\
0.40^{\mathrm{b}, \mathrm{c}}\end{array}$ & $\begin{array}{r}0.27 \pm \\
0.06^{c}\end{array}$ & $\begin{array}{c}259.15 \pm \\
0.08^{b}\end{array}$ & $\begin{array}{c}214.07 \pm \\
1.27^{\mathrm{b}}\end{array}$ \\
\hline $\begin{array}{c}\text { Indian } \\
\text { sample (T-5) }\end{array}$ & $\begin{array}{c}6.24 \pm \\
0.48^{c}\end{array}$ & $\begin{array}{c}8.64 \pm \\
0.59^{b}\end{array}$ & $\begin{array}{c}0.41 \pm \\
0.06^{\mathrm{b}}\end{array}$ & $\begin{array}{c}263.97 \pm \\
0.49^{a}\end{array}$ & $\begin{array}{c}210.58 \pm \\
0.18^{c}\end{array}$ \\
\hline $\begin{array}{c}\text { Indian } \\
\text { sample }(\mathrm{T}-6)\end{array}$ & $\begin{array}{c}5.40 \pm \\
0.91^{\mathrm{c}}\end{array}$ & $\begin{array}{c}7.11 \pm \\
0.70^{c}\end{array}$ & $\begin{array}{l}0.24 \pm \\
0.03^{c, d}\end{array}$ & $\begin{array}{c}251.35 \pm \\
1.11^{\mathrm{c}}\end{array}$ & $\begin{array}{c}106.11 \pm \\
0.27 \mathrm{e}\end{array}$ \\
\hline
\end{tabular}

Values represent the mean of triplicate \pm standard deviation; in each row, means with the same letter ( $a, b, c, d, e$, and f) are significantly different (Tukey's method, $p \leq 0.05$ ). 
Table 4. Bulk density of turmeric powder

\begin{tabular}{lc}
\hline Treatments & Bulk density $\left(\mathbf{g} / \mathbf{c m}^{3}\right)$ \\
\hline Uncured, dried as slices (T-1) & $0.32 \pm 0.001 \mathrm{e}$ \\
Water boiled, dried as slices (T-2) & $0.53 \pm 0.001^{\mathrm{d}}$ \\
Steamed boiled, dried as slices (T-3) & $0.53 \pm 0.000^{\mathrm{c}}$ \\
Indian sample (T-4) & $0.56 \pm 0.001^{\mathrm{a}}$ \\
Indian sample (T-5) & $0.55 \pm 0.001^{\mathrm{a}}$ \\
Indian sample (T-6) & $0.55 \pm 0.001^{\mathrm{b}}$ \\
\hline
\end{tabular}

\section{Determination of Color Composition}

Table 5. L*a*b* color values of turmeric powder

\begin{tabular}{|c|c|c|c|c|c|}
\hline Treatments & \multicolumn{2}{|c|}{$L^{*}$ value } & \multicolumn{2}{|c|}{$a^{*}$ value } & $\mathbf{b}^{*}$ value \\
\hline $\begin{array}{l}\text { Uncured, dried as slices (T- } \\
\text { 1) }\end{array}$ & $47.10 \pm$ & $0.96^{\mathrm{ab}}$ & $18.97 \pm$ & $0.59^{c}$ & $70.47 \pm 1.11^{c}$ \\
\hline $\begin{array}{l}\text { Water boiled, dried as slices } \\
(\mathrm{T}-2)\end{array}$ & $41.10 \pm$ & $0.30^{\mathrm{d}}$ & $21.60 \pm$ & $1.15^{\mathrm{b}}$ & $62.90 \pm 1.14^{\mathrm{d}}$ \\
\hline $\begin{array}{l}\text { Steamed boiled, dried as } \\
\text { slices (T-3) }\end{array}$ & $41.60 \pm$ & $0.61^{d}$ & $19.97 \pm$ & $0.29 \mathrm{~b}, \mathrm{c}$ & $64.43 \pm 0.31^{\mathrm{d}}$ \\
\hline Indian sample $(\mathrm{T}-4)$ & $49.23 \pm$ & $1.19 \mathrm{a}$ & $19.93 \pm$ & $0.64^{b, c}$ & $78.56 \pm 0.72^{a}$ \\
\hline Indian sample (T-5) & & & $20.96 \pm$ & $0.67 \mathrm{~b}$ & $69.27 \pm 0.71^{c}$ \\
\hline Indian sample (T-6) & $46.47 \pm$ & $0.06^{b}$ & $25.53 \pm$ & $0.78^{a}$ & $75.70 \pm 0.52^{b}$ \\
\hline
\end{tabular}

Values represent the mean of triplicate \pm standard deviation; in each row, means with the same letter (a, b, c, d, e, and f) are significantly different (Tukey's method, $p \leq 0.05$ ).

Color is an important quality attribute in the food industry because it influences the consumer's acceptance. $L^{*} a^{*} b^{*}$ are one of the color space 
that described as $\mathrm{L}^{*}$ is lightness, $\mathrm{a}^{*}$ is red/green color attribute and $\mathrm{b}^{*}$ is yellow/blue color attribute described by Pankaj et al [36]. All the $L^{*} a^{*} b^{*}$ values were described in above Table 5 . According to the results, lightness is $47.10 \pm 0.96$ in the uncured sample but $a^{*}$ value is $18.97 \pm 0.59$ that is the lowest value among samples. Not only that but also the visual inspection, the uncured sample showed light yellow color than the other samples. Munsell color value of the turmeric powder is shown in below Table 6.

Table 6. Munsell color values of turmeric powder

\begin{tabular}{cc}
\hline Sample no. & Munsell color values \\
\hline T-1 & 2.5 YR 7/10 \\
T-2 & 7.5 YR 6/10 \\
T-3 & 7.5 YR 6/10 \\
T-4 & 7.5 YR 6/10 \\
T-5 & 7.5 YR 6/10 \\
T-6 & 7.5 YR 6/10 \\
\hline
\end{tabular}

Madhusankha et al. [37] mentioned that the color of the turmeric is mainly dependent on curcumin content. Not only that but also the curing step directly affect the color of the turmeric powder. Fresh turmeric powder showed a light-yellow color. As well as cured samples showed orange-yellow color. According to the Munsell color chart, all the cured samples showed a similar color value. But directly T-1 could be identified as a low value of 2.5YR 7/10 (Table 6).

According to some research findings, heat treatment and sun-drying improved the color values of turmeric powder over fresh turmeric. The highest brightness and yellowish-ness couldn't be obtained in fresh turmeric according to the Prathapan et al [38]. 


\section{Determination of Morphology Content}
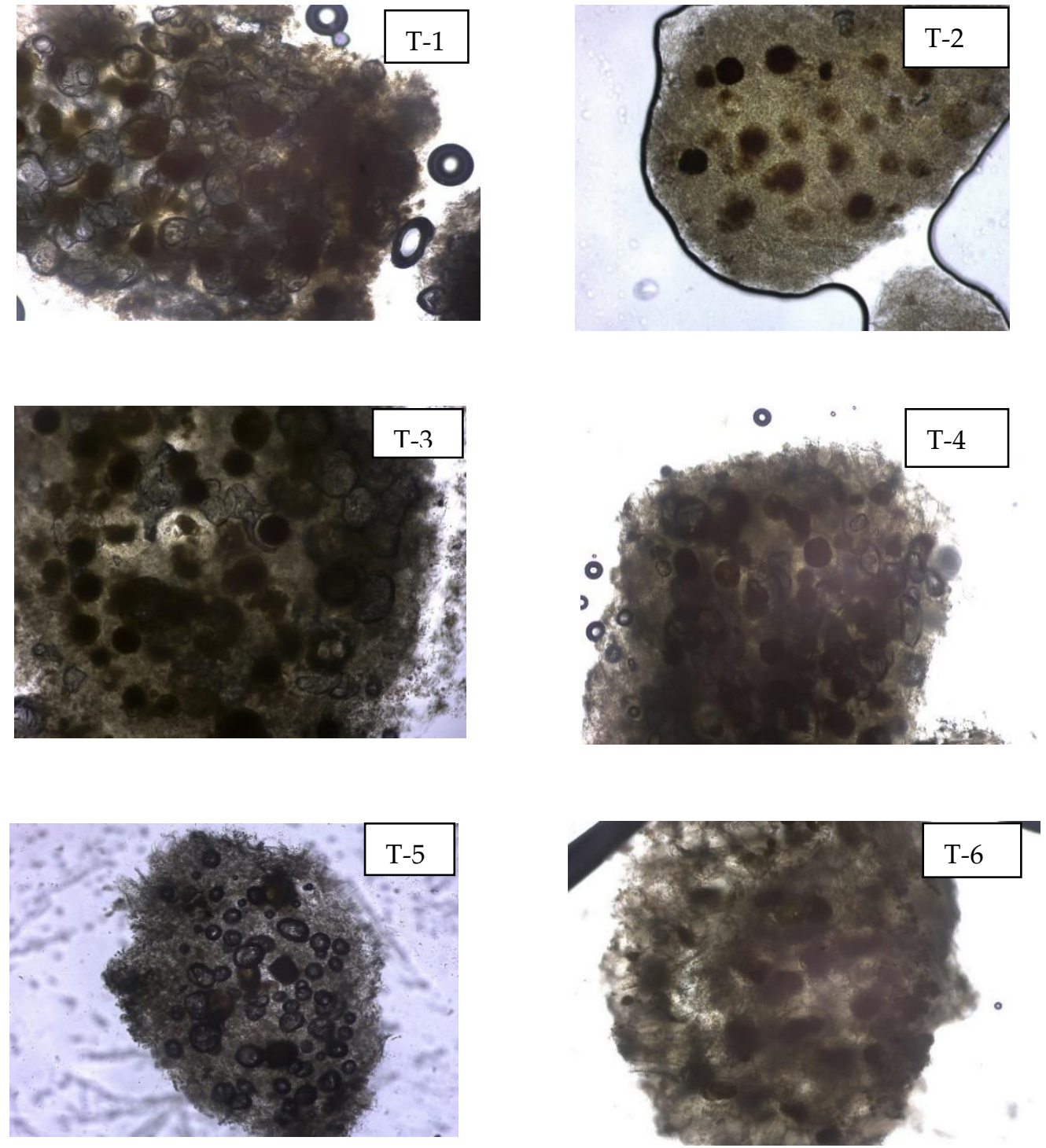

Figure 1. Morphology analysis of six different treated turmeric powder

According to the results, a considerable morphological variation was identified among turmeric samples. The characteristic orange-yellow color which is a morphological character was examined in every sample. This character varies depending on the respective curcumin content of the sample. Therefore, the characteristic orange-yellow color can be recognized as a feature that represents curcuminoids present in turmeric 
powder, T-1 sample showed less content of curcumin as well as it showed a lower orange-yellow color when checked the morphology analysis (Figure 1). Not only that but also the T-3 sample resulted in higher curcumin content (Figure 1). It showed a considerable level of orange-yellow color respective to the curcumin content.

A $50 \%$ nitric acid was used to disintegrate hard substances. This is a powerful oxidizing agent and it rapidly oxidizes and removes lignin from the tissues according to the Rafiqi et al [21]. Rafiqi et al [21] discussed this morphology analysis is most important for identifying whether there is any adulteration or not. Therefore, the characteristic morphological character can be used in the determination of the quality of turmeric powder, in terms of curcumin content.

\section{Conclusion}

In this study, six samples were subjected to analysis which was local turmeric samples collected from local farmers and imported turmeric from the Indian market. Mainly two types of curing methods were used and those are dried as slices in a greenhouse-type solar dryer. The results of this study revealed that there were significant differences $(p \leq 0.05)$ among turmeric produced locally and imported from India based on curcumin content and most of the other phytochemical parameters (moisture content, volatile oil content, oleoresin content, color values, bulk density, total flavonoid content, total phenol content, total ash content, total acid insoluble ash content and morphology). As a whole, based on the results of this study, it was revealed that turmeric sample of uncured showed fewer quality parameters (less curcumin content: $2.86 \pm 0.13 \%$, oleoresin content: $10.29 \pm 0.50 \%$, color value: $2.5 Y R$ 7/10 and long drying time) to that of turmeric powder produced by curing methods. Therefore, curing is essential for produce quality turmeric powder. Curcumin content is the most powerful principle compound in turmeric. However, Indian turmeric samples and uncured sample were comprised with less curcumin content. Sri Lanka turmeric varieties tested by curing methods, in this study showed higher curcumin contain 
than the Indian market sample. However, among the locally produced turmeric, steamed and sliced sample (T-3) showed a good quality especially for curcumin content. But water boiled and sliced sample (T2) showed a higher yield (wet to dry ratio 5.41:1), volatile oil content, and oleoresin content.

Based on the results of the study, among the locally produced turmeric, steamed and dried as slices sample (T-3) showed good quality mainly for curcumin content.

The Sri Lankan government has banned the importation of dry turmeric from other countries like India. Therefore, identification of an appropriate processing protocol was essential in such a situation. As well as Sri Lanka has the optimum conditions (soil, climate, knowledge, and labors, etc.) for turmeric production. Sri Lanka can be self-sufficient by producing own turmeric by using the correct protocol.

\section{Conflict of Interest}

The authors declare no conflicts of interest.

\section{Acknowledgment}

The authors wish to thank the Department of Biosystems Technology, Faculty of Technology, University of Sri Jayewardenepura and Central Research Station, Department of Export Agriculture, Matale.

\section{References}

[1] S. Li. Chemical composition and product quality control of turmeric (curcuma longa 1.). Pharm. Crop. 2011, 5, 28-54.

[2] A. Plotto. Turmeric: Post-Harvest Operations, Food, and Agriculture Organization of the United Nations (FAO). 2004, 1-20.

[3] S. Balasubramanian, P. Roselin, K. K. Singh, J. Zachariah, S. N. Saxena. Postharvest processing and benefits of black pepper, coriander, cinnamon, fenugreek, and turmeric spices. Crit. Rev. Food Sci. Nutr. 2016, 56, 1585-1607.

[4] D. K. Gounder, J. Lingamallu. Comparison of chemical composition and antioxidant potential of volatile oil from fresh, dried and cured turmeric (curcuma longa) rhizomes. Ind. Crops Prod. 2012, 38, 124-131.

[5] B. Z. Hmar, D. Kalita, B. Srivastava. optimization of microwave power and curing time of turmeric rhizome (curcuma longa 1.) based on textural 
degradation. LWT - Food Sci. Technol. 2017, 76, 48-56.

[6] S. M. Lokhande, R. V. Kale, A. K. Sahoo, R. C. Ranveer. Effect of curing and drying methods on recovery, curcumin and essential oil content of different cultivars of turmeric (curcuma longa 1.). Int. Food Res. J. 2013, 20, 745-749.

[7] E. Jayashree, T. J. Zachariah. Processing of turmeric (curcuma longa) by different curing methods and its effect on quality. Indian J. Agric. Sci. 2016, 86, 696-698.

[8] Jayashree. Comparison of Quality of Dry Turmeric. 2018, 27, 138-144.

[9] A. Niranjan, D. Prakash. Chemical constituents and biological activities of turmeric (curcuma longa 1.) - a review. 2008, 109-116.

[10] D. Cvetkovic, B. Danilovic. Chemical composition, antioxidant and antimicrobial activity of the turmeric essential oil (curcuma longa 1.). 2015. 4, 1925.

[11] S. Gagare, V. D. Mudgal, P. S. Champawat, A. Pisal. Standardization of curing and microwave drying of turmeric (curcuma longa) rhizomes. Int. J. Food Eng. 2015, 11, 295-300.

[12] K. P. P. Nair. Harvesting and postharvest management of turmeric. Agron. Econ. Turmeric Ginger 2013, 159-178.

[13] I. R. Chandrasekaran, S. Ganapathy, C. B. Singh. Effect of processing of turmeric rhizomes (curcuma longa 1.) on the concentrations of bioactive constituents. 2019, 18-199.

[14] G. U. Shinde, K. J. Kamble, M. G. Harkari, G. R. More. Process optimization in turmeric heat treatment by design and fabrication of blancher. Int. Conf. Environ. Agric. Eng. 2011, 15, 36-41.

[15] B. Hirko, S. Abera, H. Mitiku. Effect of curing and drying methods on the biochemical quality of turmeric (curcuma 1 onga 1.) rhizome grown in south western Ethiopia medicinal and aromatic plants. 2020, 1-8.

[16] AOAC, Official Methods of Analysis of the Association of Official's Analytical Chemists, 17th Edition. Association of Official Analytical Chemists, Arlington, Virginia. 2000.

[17] Sri Lankan Standard 613. Specification for Turmeric Powder. UDC 664.59. 1983, 3-9.

[18] G. Singh, I. P. S. Kapoor, P. Singh, C. S. de Heluani, M. P. de Lampasona, C. A. N. Catalan. Comparative study of chemical composition and antioxidant activity of fresh and dry rhizomes of turmeric (curcuma longa linn.). Food Chem. Toxicol. 2010, 48, 1026-1031.

[19] B. L. Huo, R. Lu, P. Li, Y. Liao, R. Chen. Antioxidant activity, total phenolic, and total flavonoid of extracts from the stems of jasminum nervosum lour. 2011, 62, 149-154.

[20] D. Gajula, M. Verghese, J. Boateng, L. T. Walker, L. Shackelford, S. R. Mentreddy, S. Cedric. Determination of total phenolics, flavonoids and antioxidant and chemopreventive potential of basil. 2009, 4, 130-143.

[21] U. N. Rafiqi, I. Gul, M. Saifi, N. Nasrullah, J. Ahmad, P. Dash, M. Z. Abdin. Development of internet technology tipham (tool for identity of powdered herbals through analytical microscopy) for microscopic identification of crude herbal drug. Pharmacogn. Mag. 2019, 15, S38-46. 
[22] A. G. Bhat, R. V. Hegde. Effect of pre-drying treatments and drying methods on drying time, moisture content and dry recovery of turmeric (curcuma longa 1.). 2018, 31, 315-319.

[23] S. Hirun, N. Utama-ang, P. D. Roach. Turmeric (curcuma longa 1.) drying: an optimization approach using microwave-vacuum drying. 2014, 51, 2127-2133.

[24] J. Gunasekar, K. Shaik, P. Doraisamy, S. Kamaraj. Evaluation of solar drying for post-harvest curing of turmeric (curcuma longa 1.). Ama, Agricultural Mechanization in Asia, Africa and Latin America. 2006, 37, 9-13.

[25] N. S. Dosoky, W. N. Setzer. Chemical composition and biological activities of essential oils of curcuma species. 2018, 10-17.

[26] S. N. Kane, A. Mishra, A. K. Dutta. Extraction of curcumin pigment from Indonesian local turmeric with its infrared spectra and thermal decomposition properties. J. Phys. Conf. Ser. 2016, 755.

[27] S. Haldar, G. C. Majumdar, H. N. Mishra. Modeling the kinetics of extracting oleoresin from dried turmeric (curcuma longa 1.) rhizome using acetone as solvent. J. Food Eng. 2015, 146, 116-121.

[28] T. Nisar, M. Iqbal, A. Raza, M. Safdar, F. Iftikhar, M. Waheed. Turmeric: A promising spice for phytochemical and antimicrobial activities. J. Agric. Environ. Sci. 2015, 15, 1278-1288.

[29] Y. Rao, B. Xiang. Determination of total ash and acid-insoluble ash of Chinese herbal medicine prunellae spica by near infrared spectroscopy. 2009, 129, 881886.

[30] A. A. Shahat, A. Y. Ibrahim, M. S. Alsaid. Antioxidant capacity and polyphenolic content of seven Saudi Arabian medicinal herbs traditionally used in Saudi Arabia. Indian J. Tradit. Knowl. 2015, 14, 28-35.

[31] K. Pundarikakshudu. Evaluation of turmeric (curcuma longa linn.) and its extracts from Indian market. J. Complement. Med. Altern. Healthc. 2018, 6, 25-27.

[32] S. Haldar, H. N. Mishra, G. C. Majumdar. Optimization of oleoresin extraction from curcuma longa 1 . using rsm and determination of equilibrium constant. J. Food Process. Preserv. 2016, 40, 1188-1198.

[33] F. Meng, Y. Zhou, D. Ren, R. Wang. Turmeric: A Review of Its Chemical; Elsevier Inc., 2018, 299-350.

[34] D. Sharma, A. Maheshwari. Nutritional analysis of curcuma longa 1. in different cities of west Uttar Pradesh (India). Int. J. Chem. Pharm. Sci. 2013, 4, 6-14.

[35] M. Saifullah, Y. A. Yusof, N. L. Chin, M. G. Aziz. Physicochemical and flow properties of fruit powder and their effect on the dissolution of fast dissolving fruit powder tablets. Powder Technol. 2016, 301, 396-404.

[36] P. B. Pathare, U. L. Opara. colour measurement and analysis in fresh and processed foods: A review. 2013, 36-60.

[37] G. Madhusankha, R. Thilakarathna, T. Liyanage, S. B. Navaratne. Analysis of curcumin content in Sri Lankan and Indian turmeric rhizomes and investigating its impact on the colour. Int. J. Food Sci. Nutr. 2018, 3, 3-05.

[38] A. Prathapan, M. Lukhman, C. Arumughan, A. Sundaresan, K. G. Raghu. Effect of heat treatment on curcuminoid, colour value and total polyphenols of fresh turmeric rhizome. Int. J. Food Sci. Technol. 2009, 44, 1438-1444. 